\title{
Starch-Based Adhesives for Wood/Wood Composite Bonding: Review
}

\author{
Ravindra V. Gadhave, Prakash A. Mahanwar, Pradeep T. Gadekar \\ Department Polymer and Surface Engineering, Institute of Chemical Technology, Mumbai, India \\ Email: ravi.gadhave3@gmail.com
}

How to cite this paper: Gadhave, R.V. Mahanwar, P.A. and Gadekar, P.T. (2017) Starch-Based Adhesives for Wood/Wood Composite Bonding: Review. Open Journal of Polymer Chemistry, 7, 19-32. https://doi.org/10.4236/ojpchem.2017.72002

Received: March 1, 2017

Accepted: May 22, 2017

Published: May 27, 2017

Copyright (C) 2017 by authors and Scientific Research Publishing Inc. This work is licensed under the Creative Commons Attribution International License (CC BY 4.0).

http://creativecommons.org/licenses/by/4.0/ (c) (i) Open Access

\begin{abstract}
Increasing global energy crisis and scarcity of petroleum resources has shifted focus of chemical industries to look for alternative raw material resources. The main focus of raw materials in wood adhesives, such as petroleum and natural gas [1] [2], would be gradually replaced by renewable biopolymers. Starch is a relatively inexpensive and renewable product from abundant plants, easy processing and it has been extensively used as binders, sizing materials, glues and pastes [3], but its bonding capacity is not strong enough to glue wood [4]. Extensive research has been carried out on improving the cohesive properties, especially water resistance, of starch-based adhesives. In starch-based wood adhesive many new approaches have come forward for effective use it in wood/wood composite adhesive giving comparable performance as synthetic adhesives. This review of starch-based adhesives is made with the focus on starch modification methods for improving properties of starch-based adhesives.
\end{abstract}

\section{Keywords}

Bio-Polymer, Starch, Wood Adhesives, Cross-Linking, Composite

\section{History of Wood Adhesive}

As early humans moved from a nomadic to the settled existence, they needed structures and furniture in those structures that were more permanent. Many of these were made using mechanical connectors, but humans were also looking for adhesives from plants and animals. Some, such as blood, pitch, gums, and rubber latexes, could be used as adhesives and sealants with no processing. Others, such as casein from milk, soybean proteins, and collagen adhesives, needed more processing. Animal glues from collagen, blood glues, and casein glues from milk have been used for a very long time; fish glues originated in the 1800s and soy glues in the 1900s. The first wood glues needed limited strength because they 
were used for interior applications, such as furniture. The desire to use wood more efficiently was an impetus for adhesive development in the 19th and 20th centuries. Two major early developments were the use of casein for glulam production and soy adhesives for interior plywood. Despite some success with bio-based adhesives, they were replaced by synthetic adhesives starting in the 1930s, mainly due to economics, water resistance, and ease of use. Tannins have been used for many years as a wood adhesive in locations where they are readily available and where phenolics are more limited in supply and are more costly. Carbohydrates are not used in wood bonding because of their water and thermal sensitivity. Synthetic adhesives Phenol-formaldehyde as one of the original synthetic polymers, and its application to wood bonding in the 1930s allowed for the development of durable exterior plywood. PF allowed for the development of exterior plywood, and the similar resorcinol-formaldehyde and phenol-resorcinol-formaldehyde allowed for the development of more durable glulam and other structural wood products. Urea-formaldehyde, being a low-cost, effective adhesive, has led to the expansion of existing interior products and the development of new panel products. Melamine-formaldehyde adhesives, being more water resistant but more expensive than urea-formaldehyde, has been used to improve urea-formaldehyde adhesives or used by itself as an exterior adhesive, especially outside North America. After World War II was a prime period for the development and growth of many other synthetic polymers. Some found use as very successful wood adhesives. The main ones were poly (vinyl acetate), isocyanates, and polyurethane. Others were aliphatic resins, epoxies, and construction adhesives. A main advantage of these adhesives has been that they can be formulated to have a wide range of properties, depending on the types and ratio of monomers. An important advantage of synthetics over natural products has been the ability to formulate the polymer backbone rather than trying to use what nature has provided [5]. Though synthetic adhesives have advantage in performance parameter, they have drawbacks like high formaldehyde emission, finding alternate resources for raw material is the only solution for increasing scarcity of petroleum resources, the mainly used raw materials of wood adhesives is being replaced by renewable biopolymers, such as soybean protein [6] [7] [8], natural tannin [9] [10] [11] and starch [12]. Starch is a kind of renewable, biodegradable, inexpensive, and readily available biopolymer extensively used as binders, glues, and pastes [13]-[20]. In all biopolymers stated above starch is easily available and low cost, many studies have been carried out which has given comparable results.

\section{Starch Composition and Its Structure}

Starch is an abundant, inexpensive, renewable and biodegradable polymer. It is the second most abundant natural polymer after cellulose and can be obtained mainly from the roots, stalks and seed of staple crops such as rice, corn, wheat, tapioca and potato.

Starch structure: 
Starch is a polysaccharide, basically polymers of the six-carbon sugar D-lucose, often referred to as the "building block" of starch. The structure of the monosaccharide D-glucose can be depicted in either an open-chain or a ring form (Figure 1).

Starch consisting of D-glucose units, referred to as homoglucan or glucopyranose, and two major bio-macromolecules-amylose and amylopectin.

\section{Starch composition: Amylose and amylopectin in starch}

\section{Amylose:}

Amylose is a relatively long, linear polymer composed almost entirely of $\alpha$-1,4-linked D glucopyranose (Figure 2). Amylase has a molecular weight of approximately $1 \times 10^{5}-1 \times 10^{6}$ and a degree of polymerization (DP) by number (DPn) of $324-4920$, with around 9 - 20 branch points equivalent to 3 - 11 chains

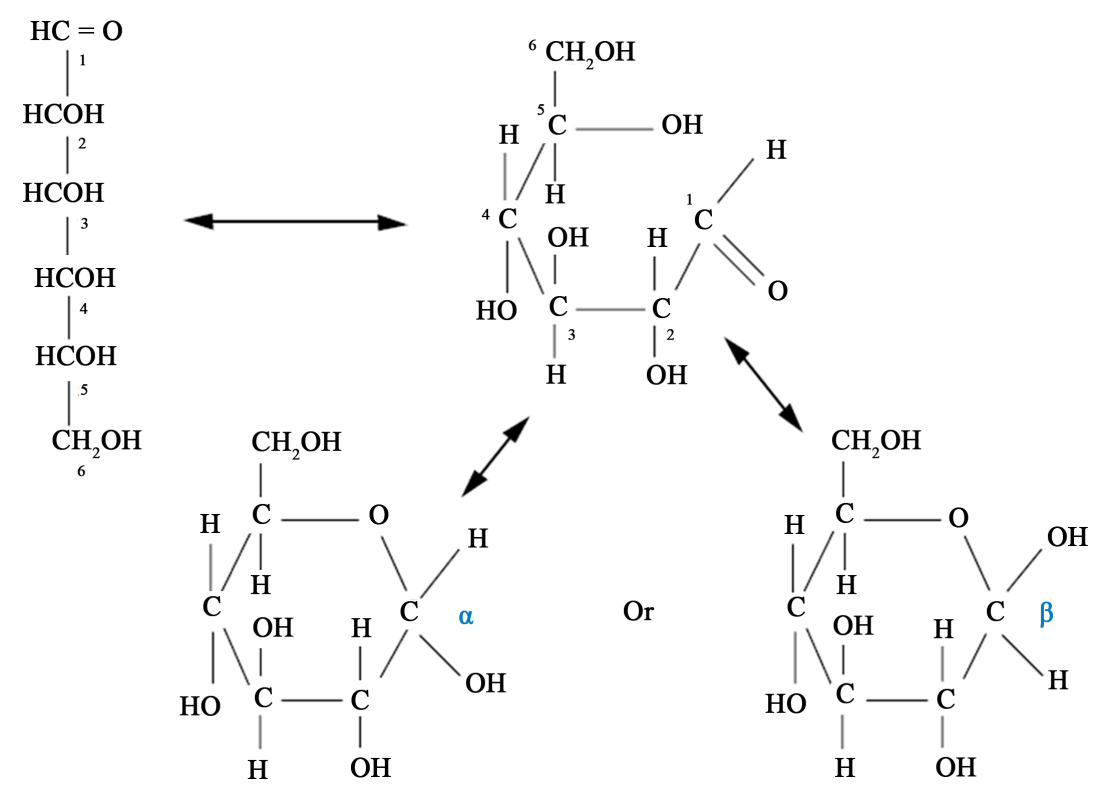

Figure 1. Open-chain and pyranose ring structures of the hexose sugar D-glucose [21].

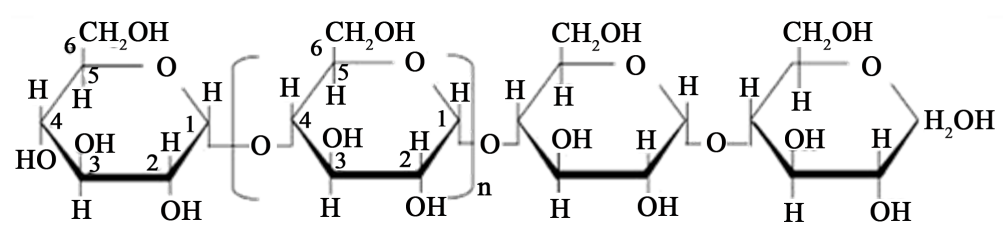

Amylose: $\alpha-(1 \rightarrow 4)$-glucan: average $n=$ ca. 1000 . The linear molecule may carry a few occasional moderately long chains linked $\alpha-(1 \rightarrow 6)$

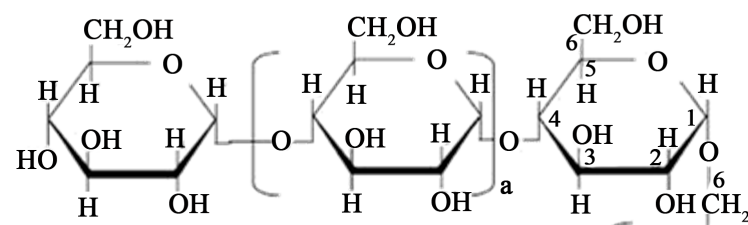

Amylopectin: $\alpha-(1 \rightarrow 6)$ branching points.

For exterior chains a $=$ ca. $12-23$.

For interior chains $b=c a .20-30$.

Both $a$ and $b$ vary according to the botanical origin.

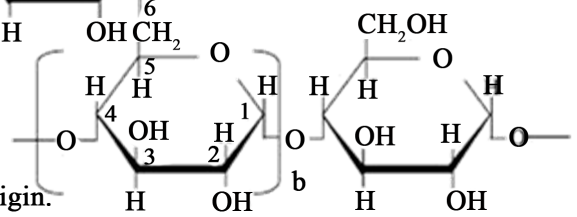

Figure 2. Structure of amylose and amylopectin. Adapted from Tester \& Karkalas (2002). 
per molecules [22]-[28]. Another well-known attribute of amylose is its ability to form a gel after the starch granule has been cooked, i.e., gelatinized and pasted. This property is evident in the behavior of certain amylose-containing starches. Corn starch, wheat starch, rice starch, and particularly high amylose corn starch isolated from hybrid corn plants are usually considered gelling starches. Gel formation is primarily the result of the re-association (i.e., retrogradation) of solubilized starch polymers after cooking and can occur quite rapidly with the linear polymer amylase [29] [30] [31] [32] [33].

\section{Amylopectin:}

The literature proposes several models for helical configurations, branch chains, cluster patterns, and molecular dimensions of amylopectin. Amylopectin, the predominant molecule in most normal starches, is a branched polymer that is much larger than amylose. Amylopectin is composed of $\alpha$-1,4-linked glucose segments connected by $\alpha-1,6$-linked branch points [34]-[40]. The small chains have an average degree of polymerization (DP) of about 15 , whereas that of the larger chains is about 45 .

\section{Other constituents of the starch granule:}

Proteins, lipids, moisture, and ash (minerals and salts) are also present in starch granules in very small quantities [41] [42] [43] [44].

\section{Different types of starch and their composition}

Amylose to amylopectin ratio within a given type of starch is a very important point to consider with respect to starch functionality as adhesives. Content of amylose and amylopectin in various starches are shown in Table 1.

\section{Starch: Used as Wood/Wood Composite Adhesive}

\subsection{To Reduce \% Formaldehyde Released in UF Resin Adhesive for Wood Composite}

Urea formaldehyde resins are preferred for bonding plywood and other wood based panels mainly due to the easy availability of raw materials required for resins at lower costs, colorless glue line and fast setting at elevated temperatures [45].

Disadvantages of UF resin:

Table 1. Approximate amylose and amylopectin content of common starches.

\begin{tabular}{ccc}
\hline Starch Type & Amylose Content (\%) & Amylopectin Content (\%) \\
\hline Dent corn & 25 & 75 \\
Waxy corn & $<1$ & $>99$ \\
Tapioca & 17 & 83 \\
Potato & 20 & 80 \\
High-amylose corn & $55-70$ (or higher) & 75 (or lower) \\
Wheat & 25 & 81 \\
Rice & 19 &
\end{tabular}


- Upon addition of water, in high temperature, cured urea formaldehyde can hydrolyze and release formaldehyde, this weakens the glue bond. For this reason it is not considered waterproof but rather water resistant and is not used for marine plywood.

- Urea Formaldehyde must be used in a well ventilated area because uncured resin is irritating and can be toxic. This is not unique as most uncured modern adhesives carry strong warnings.

It is not recommended to use of UF resins for exterior applications. So following are methods by which harmful formaldehyde emissions can be reduce by replacing few parts of UF by starch and then by using cross linkers for these blend systems.

\subsubsection{Blending of Starch with UF Resin Adhesive}

UF resin was reactively blended with various concentration of starch [46], esterified starch [47] [48] [49] and oxidized starch [50] as wood and wood composite adhesive. It is found that new system with UF-starch blending has advantages of low brittleness, low formaldehyde emission and water resistance characteristics. In esterified-starch blended UF adhesive strength found to be comparable with synthetic resin adhesive system and content of free formaldehyde was lower than $0.3 \%$ [47] [48] [49]. Oxidized starch blended UF resin adhesive has good chemical stability, insulating properties, temperature resistance, aging resistance, oil resistance and mildew resistance and environmentally-friendly starch adhesive has no harm to the human body and can be applied to wood adhesion [51] [52] [53]. UF resin and modified starch mutual react and form a net structure, water resistance of starch glue was improved, and drying time was shortened [54] [55] [56] [57]. So ultimately in above all systems few parts of UF were replaced by starch, because of which formaldehyde emissions were reduced and cost is maintained.

\subsubsection{Addition of Cross-Linker in Starch-Urea Formaldehyde Blends System}

UF-Starch blended adhesives were modified with different cross-linkers for improvement in performance properties. Starch adhesives were modified by isocyanate as cross-linker [58] [59] [60] [61] [62] [70] as well as starch adhesive with polyvinyl alcohol, borax, and carboxy methyl cellulose as system [63] [64] [65] [66] for wood composite can be prepared with isocyante as cross-linker, influence factors on the bonding strength and water resistance of starch adhesive were studied by different solid content, adding isocyanate and additives like PVA, Acrylic emulsion. Bonding strength and water resistance were improved significantly by adding additives and isocyanates to starch. An environmentally friendly wood adhesive was developed by cross-linking cornstarch-UF blend system with hexamethoxymethylmelamine. It exhibited excellent mechanical properties comparable to many of the commercially available urea-formaldehyde plywood adhesives used for interior applications [67]. So by above all systems not only reduced formaldehyde emissions were achieved but improved water resistance and improved performance properties were also achieved and 
cost is also maintained.

\subsection{Alternative for UF/MUF Resin Adhesive for Wood/Wood Composite}

Different studies on starch adhesives proved that it can be used as alternative for conventional amino resin (UF, UMF, PF) adhesives which is been discussed follows.

\subsubsection{Modification of Starch Using Different Types of Cross-Linkers}

Environment friendly Starch adhesives can also totally replace UF adhesives for wood and wood composite application. By addition of cross-linkers like iscoyanates [68]-[76], Melamine formaldehyde with which water resistance, extremely low formaldehyde emission and comparable performance properties can be achieved. In other study it was stated three different cross-linkers such as glutaraldehyde, glyoxal and dimethyloldihydroxyethyleneurea used in wood composites.

\subsubsection{Modification of Starch by Acid}

Citric acid, borax, sodium hypochlorite were utilized as oxidizing agents for starch and it was found to reduce the moisture sorption, the molecular movement and swelling at high relative humidity [77] [78]. Tapioca starch was chemically modified with urea or polyvinyl alcohol in the presence of borate as crosslinker and catalyst to reduce its water sensitivity [79] [80] [81] [82] [83]. The adhesive prepared by oxidation of the corn starch has good fluidity, milky white, fine and glossy appearance, and significantly improved dry strength and wet strength, good machining property and good water resistance [84]. Oxidation of starch by sodium hypochlorite under aqueous alkaline conditions with the aid of the catalysis of nickel sulphate at room temperature was investigated. Optimization of starch oxidation is desirable to achieve the highest initial tack and bonding strength. Under the optimum condition, $98.7 \%$ of the initial tack and 11.4 $\mathrm{N} / 25 \mathrm{~mm}$ of the bonding strength were obtained respectively. The modified starch adhesive showed great potential for industrial application [85] [86] [87] [88]. Sodium dodecyl sulfate was also used to improve the performance of water resistance properties in starch-based wood adhesive [89].

\subsubsection{Addition of Emulsion in Starch}

A natural rubber (NR) latex and starch was added as an adhesive to synthesize the medium density fiber (MDF) board panels. The study was aimed on increasing the mechanical and physical properties of MDF by using NR latex and starch as an adhesive. The results of this study indicated that starch can be used as a viable alternative binder with NR latex [90]. Starch-grafted-polyvinyl acetate (starch-g-PVAc) and epoxy resin can be used as high cohesive energy component to improve the dry shear strength of the starch adhesive [91].

\subsubsection{Blending with Biopolymer}

Protein-starch composite [92] [93] tannin-starch composite [94] can also be 
used for wood and wood composites adhesives which is eco-friendly system with zero formaldehyde emissions. Aldehyde hardeners like glyoxal, dioxal can be used for enhancement of properties.

\subsection{Replacement of Synthetic Polymer by Starch in Polyvinyl Acetate Wood Adhesive}

\subsubsection{Physical Blending of Starch with Polyvinyl Acetate Emulsion}

Synthetic polymers in water based systems like polyvinyl acetate are commonly used for wood and wood composite adhesive applications for various advantages like excellent strength performance, cost effective, non toxic etc. Few parts can be replaced by renewable biopolymer starch which is cost effective and having adhesive properties naturally. Various commercial adhesive with PVAc-starch blend for lamination is been used widely.

\subsubsection{Starch Grafted Polyvinyl Acetate Emulsion Adhesive for Wood} Graft polymerization of vinyl acetate on waxy corn starch was done to prepare wood adhesive which can be used at room temperature giving excellent bonding performance [95] [96]. Graft copolymerization enhanced the thermal stability, which improved the bonding strength and water resistance. The improved properties were attributed to the modified microstructure of the graft-copolymerized starch-based adhesive [97] [98]. Therefore, Modified starch produced from graft polymerization with vinyl acetate and butyl acrylate has been tried to use as a wood adhesive [99]. Adhesives made of conventional materials when compared with biopolymer-based adhesives are usually too weak for practical use [100], so the structural strength of starch-based adhesive should be strengthened to achieve high performance as a wood adhesive. For improving the performance of a corn starch based bio-adhesive, corn starch graft glycidyl methacrylate (AS- $g$-GMA) adhesive was prepared [101].

\subsubsection{Addition of $\mathrm{MMT} / \mathrm{SiO}_{2}$ in Starch Stabilized Polyvinyl Acetate Emulsion Adhesive}

Silica nanoparticles and montmorillonite (MMT) were used to improve the bonding capacity of renewable starch-based wood adhesive in this study [102] [103] [104] [105].

\subsection{Starch as Well as Filler Based Hot Melt Adhesive}

The hot-melt adhesive consisting starch found to be less harmful, more environmentally friendly, involves reduced production costs [106]. Starch ethers and esters (e.g., starch acetate) can be subjected to further processing and used as a component in hot melt adhesives. The advantage of this type of material is that lower melting points can be achieved which assists both compounding and application to thermally sensitive substrates [107] [108] [109] [110] [111].

\section{Future Prospects}

The main reasons for the increasing interest in starch-based adhesives are the legislation and increasing interest in environmentally friendly adhesives. Most of 
the thermosetting adhesive resins used today in the wood composite industries depend on petrochemicals. UF, UMF, PF are widely used in the wood composite industries and are formaldehyde emitting source. Society recognizes the protection of health and the environment and consequently the use of synthetic products as major environmental problems thus encourages the use of renewable natural resources. Starch is an ideal material for manufacturing of woodcomposite adhesives due to low cost, high free hydroxyl content, easy processing and treatment. Starch based adhesives have a limited water resistance, but it can be modified by cross-linking of starch. A lot of research has already been done on modification and cross-linking of starch with synthetic materials. However, the challenge remains to produce the starch-based adhesive with high water resistance and fungal resistance similar like synthetic resin adhesives.

\section{References}

[1] Imam, S.H., Gordon, S.H., Mao, L. and Chen, L. (2001) Environmentally Friendly Wood Adhesive from a Renewable Plant Polymer: Characteristics and Optimization Polymer Degradation and Stability, 73, 529-533.

[2] Pizzi, A. (2013) Bioadhesives for Wood and Fibres. Reviews of Adhesion and Adhesives, 1, 88-113.

[3] Kennedy, H.M. (1989) Starch- and Dextrin-Based Adhesives. In: Hemingway, R.W., Conner, A.H. and Branham, S.J., Eds., Adhesives from Renewable Resources, ACS Publications, Washington DC, 326-336.

[4] Xu, W.B., Shi, J.Y. and Wang, S.M. (2014) Study on Heat Aging Properties of Starch Based Aqueous Polymer Isocyanate Adhesive for Wood. Advanced Materials Research, 933, 138-143. https://doi.org/10.4028/www.scientific.net/amr.933.138

[5] Frihart, C.R. (2015) Introduction to Special Issue: Wood Adhesives: Past, Present, and Future. Forest Products Journal, 65, 4-8. https://doi.org/10.13073/65.1-2.4

[6] Vnučec, D., Goršek, A., Kutnar, A. and Mikuljan, M. (2015) Thermal Modification of Soy Proteins in the Vacuum Chamber and Wood Adhesion. Wood Science and Technology, 49, 225-239.

[7] Ciannamea, E.M., Stefani, P.M. and Ruseckaite, R.A (2010) Medium-Density Particleboards from Modified Rice Husks and Soybean Protein Concentrate-Based Adhesives. Bioresource Technology, 101, 818-825.

[8] Extance, A. (2008) Natural Adhesives Today-And Tomorrow. SpecialChem. http://www.specialchem4adhesives.com/resources/articles/article.aspx?id=2243

[9] Navarrete, P., Pizzi, A., Bertaud, F. and Rigolet, S. (2011) Condensed Tannin Reactivity Inhibition by Internal Rearrangements: Detection by CP-MAS 13C NMR. Maderas, 13, 59-68.

[10] Kim, S. (2009) Environment-Friendly Adhesives for Surface Bonding of WoodBased Flooring Using Natural Tannin to Reduce Formaldehyde and TVOC Emission. Bioresource Technology, 100, 744-748.

[11] Pizzi, A. (2006) Recent Developments in Eco-Efficient Bio-Based Adhesives for Wood Bonding: Opportunities and Issues. Journal of Adhesion Science and Technology, 20, 829-846. https://doi.org/10.1163/156856106777638635

[12] Conner, A.H., Lorenz, L.F. and River, B.H. (1989) Carbohydrate-Modified Phenol-Formaldehyde Resins Formulated at Neutral Conditions. ACS Symposium Series, 385, 355-369. 
[13] Kennedy, H.M. and Fischer, A.C. (1983) Chap. XX-Starch Use in Foods. In: Whistler, R.L., Be Miller, J.N. and Paschall, E.F., Eds., Starch: Chemistry and Technology, 2nd Edition, Academic Press, Inc., New York.

[14] Wang, Z.J., Li, Z.F., Gu, Z.B., Hong, Y. and Cheng, L. (2012) Preparation, Characterization and Properties of Starch-Based Wood Adhesive. Carbohydrate Polymers, 88, 699-706.

[15] Athawale, V.D. and Lele, V. (2000) Thermal Studies on Granular Maize Starch and Its Graft Copolymers with Vinyl Monomers. Starch (Stärke), 52, 205-213.

[16] Goñi, I., Gurruchaga, M., Valero, M. and Guzman, G.M. (1983) Graft Polymerization of Acrylic Monomers onto Starch Fractions. I. Effect of Reaction Time on Grafting Methyl Methacrylate onto Amylose. Journal of Polymer Science Part A: Polymer Chemistry, 21, 2573-2580. https://doi.org/10.1002/pol.1983.170210837

[17] Gurruchaga, M., Goñi, I., Valero, M. and Guzmán, G.M. (1992) Graft Copolymerization of Hydroxylic Methacrylates and Ethyl Acrylate onto Amylopectin. Polymer, 33, 2860-2862.

[18] Kaewtatip, K. and Tanrattanakul, V. (2008) Preparation of Cassava Starch Grafted with Polystyrene by Suspension Polymerization. Carbohydrate Polymers, 73, 647655.

[19] Kim, S. and Kim, H.-J. (2006) Thermal Stability and Viscoelastic Properties of MF/PVAc Hybrid Resins on the Adhesion for Engineered Flooring in under Heating System; ONDOL. Thermochimica Acta, 444, 134-140.

[20] Meshram, M.W., Patil, V.V., Mhaske, S.T. and Thorat, B.N. (2009) Graft Copolymers of Starch and Its Application in Textiles. Carbohydrate Polymers, 75, 71-78.

[21] Hood, L.F. (1982) Current Concepts of Starch Structure. In: Lineback, D.R. and Inglett, G.E., Eds., Food Carbohydrates, AVI, Westport, CT, 218-224.

[22] Buléon, A., Colonna, P., Planchot, V. and Ball, S. (1998) Starch Granules: Structure and Biosynthesis. International Journal of Biological Macromolecules, 23, 85-112.

[23] Biliaderis, C. (2010) ChemInform Abstract: Structures and Phase Transitions of Starch Polymers. ChemInform, 29.

[24] Mua, J. and Jackson, D. (1997) Fine Structure of Corn Amylose and Amylopectin Fractions with Various Molecular Weights. Journal of Agricultural and Food Chemistry, 45, 3840-3847. https://doi.org/10.1021/jf960877a

[25] Takeda, Y., Hizukuri, S., Takeda, C. and Suzuki, A. (1987) Structures of Branched Molecules of Amyloses of Various Origins, and Molar Fractions of Branched and Unbranched Molecules. Carbohydrate Research, 165, 139-145.

[26] Wang, I. and White, P. (1994) Structure and Properties of Amylose, Amylopectin, and Intermediate Materials of Oat Starches. Cereal Chemistry, 71, 263-268.

[27] Yoshimoto, Y., Tashiro, J., Takenouchi, T. and Takeda, Y. (2000) Molecular Structure and Some Physicochemical Properties of High-Amylose Barley Starches. Cereal Chemistry, 77, 279-285. https://doi.org/10.1094/CCHEM.2000.77.3.279

[28] Yoshimoto, Y., Takenouchi, T. and Tekeda, Y. (2002) Molecular Structure and Some Physicochemical Properties of Waxy and Low-Amylose Barley Starches. Carbohydrate Polymers, 47, 159-167.

[29] Wang, L.Z. and White, P.J. (1994) Structure and Properties of Amylose, Amylopectin and Intermediate Material of Oat Starches. Cereal Chemistry, 71, 263-268.

[30] Tester, R.F. and Karkalas, J. (2002) Starch. In: Steinbüchel, A. (Series Ed.), Vandamme, E.J., De Baets, S. and Steinbüchel, A. (Vol. Eds. ), Biopolymers, Vol. 6, Polysaccharides. II. Polysaccharides from Eukaryotes, Wiley-VCH, Weinheim, 381- 
438.

[31] Tester, R.F. and Morrison, W.R. (1990) Swelling and Gelatinisation of Cereal Starches. I. Effects of Amylopectin, Amylose and Lipids. Cereal Chemistry, 67, 551-557.

[32] Tester, R.F. and Morrison, W.R. (1990) Swelling and Gelatinisation of Cereal Starches. II. Waxy Rice Starches. Cereal Chemistry, 67, 558-563.

[33] Tester, R.F. and Morrison, W.R. (1992) Swelling and Gelatinisation of Cereal Starches. III. Some Properties of Waxy and Normal Non-Waxy Barley Starches. Cereal Chemistry, 69, 645-658.

[34] Takeda, Y., Shibahara, S. and Hanashiro, I. (2003) Examination of the Structure of Amylopectin Molecules by Fluorescent Labelling. Carbohydrate Research, 338, 471475.

[35] Hizukuri, S. (1996) Starch: Analytical Aspect. In: Eliasson, A.-C., Ed., Carbohydrates in Food, Marcel Dekker, NY, 347-429.

[36] French, D. (1972) Fine Structure of Starch and Its Relationship to the Organisation of Starch Granules. Journal of the Japanese Society of Starch Science, 19, 8-25.

[37] Banks, W. and Greenwood, C.T. (1975) Starch and Its Components. Edinburgh University Press, Edinburgh.

[38] Lineback, D.R. (1984) The Starch Granule: Organisation and Properties. Bakers Digest, 58, 16-21.

[39] Lineback, D.L. (1986) Current Concepts of Starch Structure and Its Impact on Properties. Journal of the Japanese Society of Starch Science, 33, 80-88. https://doi.org/10.5458/jag1972.33.80

[40] Yashushi, Y.B., Takenouchi, T. and Takeda, Y. (2002) Molecular Structure and Some Physicochemical Properties of Waxy and Low-Amylose Barley Starches. Carbohydrate Polymers, 47, 159-167.

[41] Rayas-Duarte, P., Robinson, S.F. and Freeman, T.P. (1995) In Situ Location of a Starch Granule Protein in Durum Wheat Endosperm by Immune-Cytochemistry. Cereal Chemistry, 72, 269-274.

[42] Greenwell, P. and Schofield, J.D. (1986) A Starch Granule Protein Associated with Endosperm Softness in Wheat. Cereal Chemistry, 63, 379-380.

[43] Acker, L. (1982) The Role of Starch Lipids among Cereal Lipids, Their Composition and Their Importance for the Baking Properties of Wheat Flours. Getreide, Mehl und Brot, 36, 291-295.

[44] Biliaderis, C.J., Page, C.M. and Maurice, T.J. (1986) On the Multiple Melting Transitions of Starch/Monoglyceride Systems. Food Chemistry, 22, 279-295.

[45] http://www. ipirti. gov. in/adhesives3. html

[46] Dimas, B.J., Osemeahon, S.A., Maitera, O.N. and Hotton, A.J. (2013) Influence of Starch Addition on Properties of Urea Formaldehyde/Starch Copolymer Blends for Application as a Binder in the Coating Industry. Journal of Environmental Chemistry and Ecotoxicology, 5, 181-189.

[47] Z.-Z. Xu, Shuang, H. and Tu, Y.-Q. (2013) Esterified-Starch Modified Urea Formaldehyde Adhesive. CN 102898987 A 12, 30 January 2013.

[48] Liu, R. (2013) Modified Urea-Formaldehyde Resin. CN 103360559 A 13, 23 October 2013.

[49] Zhu, L. (2014) Preparation Method for High-Strength Water-Resistant Starch Adhesive for Corrugated Paperboards. CN 104119816 A 14, 29 October 2014.

[50] Ni, K. (2014) Oxidized Starch Modified Urea-Formaldehyde Resin Adhesive. CN 
103911103 A 15, 9 July 2014.

[51] Chen, Y. (2014) Method for Producing Urea-Formaldehyde Resin Adhesive. CN 104178070 A 16, 3 December 2014.

[52] Bloembergen, S., Kappen, F. and Beelen, B. (2005) Environmentally Friendly BioPolymer Adhesives and Applications Based Thereon. US 6921430 B2, 26 July 2005.

[53] Dunkey, M. (1997) Urea-Formaldehyde (UF) Adhesive Resins for Wood. International Journal of Adhesion and Adhesives, 18, 95-107.

[54] Yu, S. and Zhang, H.B. (2008) Starch Adhesive for Producing Highly Intensified Water-Proof Corrugated Paper. CN 101134881 A, 5 March 2008.

[55] Liu, Y.-Y., Zhang, Y.-M. and Li, Q.-Y. (2014) Environmental Moisture MDF with Urea-Formaldehyde Resin Adhesive and Composite Additives and Production Methods. CN 102408855 B, 18 June 2014.

[56] Lv, Z., Duan, X.L., Xu, S., Deng, Z., Zhou, Y. and Jiang, Z. (2014) Manufacturing Method of Low-Formaldehyde-Release-Amount Plywood. CN 103484046 B, 31 December 2014.

[57] Pizzi, A. (1983) Wood Adhesives Chemistry and Technology. Marcel Dekker, New York.

[58] Gu, J.Y., Zuo, Y. F., Zhang, Y.H., Tan, Y.H., Zhu, L.B. and Shen, J. (2010) Preparation of Plywood Using Starch Adhesives Modified with Isocyanate. Applied $\mathrm{Me}$ chanics and Materials, 26-28, 1065-1068. https://doi.org/10.4028/www.scientific.net/AMM.26-28.1065

[59] Li, L.H., Liu, G.J. and Zhang, G.X. (2008) The Latest Progress in Study on Starch-Based Adhesives. Chemistry and Adhesive, 30, 50-53.

[60] Liu, Y.H., Ruan, R.S. and Zhang, J.S. (2005) Research Situation of Starch Based Wood Adhesives. Chemistry and Adhesive, 27, 358-361.

[61] Zhang, Y.H., Gu, J.Y. and Tan, H.Y. (2009) Preparation of the Plywood Using UF Resin Modified with Blocked Isocyanates as Bonding Agent. China Forest Products Industry, 36, 17-19.

[62] Huang, Y.B. and Huo, Q.Y. (2006) The Application of Isocyanates Adhesive in Timber Industry. Journal of HeiLongJiang Ecological Engineering Vocational College, No. 6, 34-35.

[63] Qiao, Z., Gu, J., Lv, S., Cao, J., Tan, H. and Zhang, V. (2015) Preparation and Properties of Isocyanate Prepolymer/Corn Starch Adhesive. Journal of Adhesion Science and Technology, 29.

[64] Shi, J. (2007) Starch Based Wood Adhesive API and Curing and Aging Mechanism. Journal of Northeast Forestry University, 90-123.

[65] Shi, J.Y. and Tang, Y.Y. (2010) Study on the Rice Straw Particleboard by StarchBased API Adhesive. Advanced Materials Research, 113-116, 1017-1020. https://doi.org/10.4028/www.scientific.net/AMR.113-116.1017

[66] Du, S. and Zhang, C. (2003) Study on Modified Starch of Non-Formaldehyde Adhesive. Chinese Adhesive, 10, 11-13.

[67] Imam, S.H., Mao, L.J., Chen, L. and Greene, R.V. (1999) Wood Adhesive from Crosslinked Poly(Vinyl Alcohol) and Partially Gelatinized Starch: Preparation and Properties. Starch, 51, 225-229. https://doi.org/10.1002/(SICI)1521-379X(199906)51:6<225::AID-STAR225>3.0.CO; $\underline{2-\mathrm{F}}$

[68] Li, J., Shen, K., Cai, J., Lai, Q. and Zheng, X. (2010) Environmentally-Friendly Starch Adhesive. CN 101735741 A 17, 16 June 2010. 
[69] Jarowekno, W. (1977) Starch Based Adhesives. In: Skeist, I., Ed., Adhesive Handbook, Van Nostrand Reinhold Company, New York, 192-211.

[70] Zhang, Y. and Li, L. (2014) Reaction Mechanism of Carboxymethyl Starch-Based Wood Adhesive. Comput. Model. New Technol., 18, 1150-1155.

[71] Gao, Z.H., Wang, W.B., Zhao, Z.Y. and Guo, M.R. (2011) Novel Whey ProteinBased Aqueous Polymer-Isocyanate Adhesive for Glulam. Journal of Applied Polymer Science, 120, 220-225. https://doi.org/10.1002/app.33025

[72] Yang, L., Liu, J., Du, C., et al. (2013) Preparation and Properties of Cornstarch Adhesives. Advance Journal of Food Science and Technology, 5, 1068-1072.

[73] Xie, F., Yu, L., Liu, H. and Chen, L. (2006) Starch Modification Using Reactive Extrusion. Starch, 58, 131-139.

[74] Kaur, B., Ariffin, F., Bhat, R. and Karim, A.A. (2012) Progress in Starch Modification in the Last Decade. Food Hydrocolloids, 26, 398-404.

[75] Baishya, P. and Maji, T.K. (2014) Studies on Effects of Different Cross-Linkers on the Properties of Starch-Based Wood Composites. ACS Sustainable Chemistry \& Engineering, 2, 1760-1768. https://doi.org/10.1021/sc5002325

[76] Gu, Z., Cheng, L., Wang, P., Li, Z. and Hong, Y. (2014) Preparation Method of Starch Adhesive Used for Artificial Board Production. CN 102604560 B, 9 April 2014.

[77] Olsson, E. (2013) Effects of Citric Acid on Starch-Based Barrier Coatings. Karlstad University, Sweden.

[78] Sridach, W., Jonjankiat, S. and Wittaya, T. (2013) Effect of Citric Acid, PVOH, and Starch Ratio on the Properties of Cross-Linked Poly(Vinyl Alcohol)/Starch Adhesives. Journal of Adhesion Science and Technology, 27, 1727-1738.

https://doi.org/10.1080/01694243.2012.753394

[79] Sarwono, A., Man, Z.B. and Bustam, M.A. (2014) Effect of Urea and Borate on Water Uptake of Urea Modified Tapioca Starch Film. Journal of Applied Science and Agriculture, 9, 95-101.

[80] Huang, Z. (2006) Environment-Friendly Type Wood-Based Panel Adhesive without MTBE. CN 1884413 A, 27 December 2006.

[81] Zhang, X. and Wang, L. (2013) Formaldehyde-Free Veneering Glue Applicable to Gluing of Core Veneer and Panel of Core Board and Manufacturing Method Thereof. CN 103436202 A, 11 December 2013.

[82] Li, P., Guan, Y. and Liu, X. (2014) Starch Modified Polyvinyl Alcohol EnvironmentFriendly Adhesive for Buildings and Preparation Method of Adhesive. CN 103897639 A, 2 July 2014.

[83] Shi, D. (2014) Corn Starch Adhesive and Preparation Method Thereof. CN 103333635 A, 2 October 2014.

[84] Zhang, T. (2014) Production Method of Biomass Adhesive Glued Board. CN 104059578 A, 24 September 2014.

[85] Luo, P., Liu, Y., Zhao, X., Song, P., Tan, N. and Sun, M. (2011) Development of a Starch Adhesive for Corrugated Board under Room Temperature. Advanced Materials Research, 179-180, 812-817. https://doi.org/10.4028/www.scientific.net/AMR.179-180.812

[86] Onusseit, H. (1992) Starch in Industrial Adhesives: New Developments. Industrial Crops and Products, 1, 141-146.

[87] Moubarik, A., Pizzi, A., Allal, A., et al. (2009) Cornstarch and Tannin in PhenolFormaldehyde Resins for Plywood Production. Industrial Crops and Products, 30, 
188-193.

[88] Conner, A.H. (1998) Carbohydrates in Adhesives: Introduction and Historical Perspective. ACS Symposium Series, 385, 271-288.

[89] Li, Z., Wang, J., Chong, L., Gu, Z., Hong, Y. and Kowalczyk, A. (2014) Improving the Performance of Starch-Based Wood Adhesive by Using Sodium Dodecyl Sulphate. Carbohydrate Polymers, 99, 579-583.

[90] Akbari, S., Gupta, A., Khan, T.A., Jamari, S.S. and Poddar, P. (2014) Synthesis and Characterization of Medium Density Fiber Board by Using Mixture of Natural Rubber Latex and Starch as an Adhesive. Journal of the Indian Academy of Wood Science, 11, 109-115. https://doi.org/10.1007/s13196-014-0124-0

[91] Nie, Y., Tian, X., Liu, Y., Wu, K. and Wang, J. (2013) Research on Starch-g-Polyvinyl Acetate and Epoxy Resin-Modified Corn Starch Adhesive. Polymer Composites, 34, 77-87. https://doi.org/10.1002/pc.22379

[92] Anderson, K.R., Porter, M.A. and Satyavolu, J.V. (2011) Protein and Starch Compositions, Methods for Making and Uses Thereof. EP 2307494 A1, 13 April 2011.

[93] Weakley, F.B., Carr, M.E. and Mehltretter, C.L. (1972) Dialdehyde Starch in Paper Coatings Containing Soy Flour-Isolated Soy Protein Adhesive. Starch, 24, 191-194. https://doi.org/10.1002/star.19720240604

[94] Moubrik, A., Allal, A., Pizzi, A., Charrier, F. and Charrier, B. (2010) Preparation and Mechanical Characterization of Particleboard Made from Maritime Pine and Glued with Bio-Adhesives Based on Cornstarch and Tannins. Maderas. Ciencia $y$ Tecnología, 12, 189-197. https://doi.org/10.4067/s0718-221x2010000300004

[95] Wang, Z., Gu, Z., Li, Z., Hong, Y. and Cheng, L. (2013) Effects of Emulsifier on the Bonding Performance and Freeze-Thaw Stability of Starch-Based Wood Adhesive. Cellulose, 20, 2583-2590. https://doi.org/10.1007/s10570-013-9984-5

[96] Samaha, S.H., Nasr, H.E. and Hebeish, A. (2005) Synthesis and Characterization of Starch-Poly(Vinyl Acetate) Graft Copolymers and Their Saponified Form. Journal of Polymer Research, 12, 343-353. https://doi.org/10.1007/s10965-004-7937-2

[97] Zhang, Y., Ding, L., Gu, J., Tan, H. and Zhu, L. (2015) Preparation and Properties of a Starch-Based Wood Adhesive with High Bonding Strength and Water Resistance. Carbohydrate Polymers, 115, 32-37.

[98] Ruan, H., Chen, Q.-H., Fu, M.-L., Xu, Q. and He, G.-Q. (2009) Preparation and Properties of Octenyl Succinic Anhydride Modified Potato Starch. Food Chemistry, $114,81-86$.

[99] Wu, Y., Lv, C. and Han, M. (2009) Synthesis and Performance Study of Polybasic Starch Graft Copolymerization Function Materials. Advanced Materials Research, 79-82, 43-46. https://doi.org/10.4028/www.scientific.net/AMR.79-82.43

[100] Bordes, P., Pollet, E. and Avérous, L. (2009) Nano-Biocomposites: Biodegradable Polyester/Nanoclay Systems. Progress in Polymer Science, 34, 125-155.

[101] Zhang, S.F., Zhou, L.L., Gao, Q., Guo, X.X., Chen, L.O., Han, C.R. and Li, J.Z. (2012) Preparation and Performance of Bio-Adhesive Based on Acorn Starch Graft Glycidyl Methacrylate. Applied Mechanics and Materials, 121-126, 293-296.

[102] Wang, Z., Gu, Z., Hong, Y., Cheng, L. and Li, Z. (2011) Bonding Strength and Water Resistance of Starch-Based Wood Adhesive Improved by Silica Nanoparticles. Carbohydrate Polymers, 86, 72-76.

[103] Tang, S., Zou, P., Xiong, H. and Tang, H. (2008) Effect of Nano-SiO ${ }_{2}$ on the Performance of Starch/Polyvinyl Alcohol Blend Films. Carbohydrate Polymers, 72, 521-526. 
[104] Li, Z., Wang, J., Li, C., Gu, Z., Cheng, L. and Hong, Y. (2015) Effects of Montmorillonite Addition on the Performance of Starch-Based Wood Adhesive. Carbohydrate Polymers, 115, 394-400.

[105] Kaboorani, A. and Riedl, B. (2011) Effects of Adding Nano-Clay on Performance of Polyvinyl Acetate (PVA) as a Wood Adhesive. Composites, A: Applied Science and Manufacturing, 42, 1031-1039.

[106] Jeon, Y.S., Lee, S.N., Yoon, J.Y., Lee, J.S. and Kim, S.O. (2014) Starch-Based Hot-Melt Adhesive. WO 2013100301 A1, 4 July 2014.

[107] Biobased Components in Hot Melt Adhesive Formulation. SpecialChem, Edward M Petrie, 11 July 2012.

[108] Zhang, Z., Macquarrie, D.J., Clark, J.H. and Matharu, A.S. (2014) Chemical Modification of Starch and the Application of Expanded Starch and Its Esters in Hot Melt Adhesive. RSC Advances, 4, 41947-41955. https://doi.org/10.1039/C4RA08027K

[109] Lewis, D.N., Schutte, G., Westerhof, H., Janssen, J. and Ketty, W.E. (2008) Environmentally Degradable Polymeric Compounds Their Preparation and Use as Hot Melt Adhesive. US Patent, 7465770, 16 December 2008.

[110] Billmers, R.J., Paul, C.W., Hatfield, S.F. and Kauffman, T.F. (1994) Starch Ester Based Hot Melt Adhesive. US Patent, 5360845, 1 November 1994.

[111] Kauffman, T.F., Wieczorek Jr., J. and Hatfield, S.F. (1996) Starch Based Hot Melt Adhesives for Cigarettes. US Patent, 5498224, 12 March 1996.

\section{Submit or recommend next manuscript to SCIRP and we will provide best} service for you:

Accepting pre-submission inquiries through Email, Facebook, LinkedIn, Twitter, etc. A wide selection of journals (inclusive of 9 subjects, more than 200 journals)

Providing 24-hour high-quality service

User-friendly online submission system

Fair and swift peer-review system

Efficient typesetting and proofreading procedure

Display of the result of downloads and visits, as well as the number of cited articles

Maximum dissemination of your research work

Submit your manuscript at: http://papersubmission.scirp.org/

Or contact ojpchem@scirp.org 